This item was submitted to Loughborough's Research Repository by the author.

Items in Figshare are protected by copyright, with all rights reserved, unless otherwise indicated.

\title{
Patterns of press partisanship in the 2010 General Election
}

PLEASE CITE THE PUBLISHED VERSION

http://dx.doi.org/10.1057/bp.2010.18

\section{PUBLISHER}

(C) Macmillan Publishers Ltd.

\section{VERSION}

AM (Accepted Manuscript)

LICENCE

CC BY-NC-ND 4.0

\section{REPOSITORY RECORD}

Wring, Dominic, and David Deacon. 2019. "Patterns of Press Partisanship in the 2010 General Election". figshare. https://hdl.handle.net/2134/13223. 
This item was submitted to Loughborough's Institutional Repository (https://dspace.lboro.ac.uk/) by the author and is made available under the following Creative Commons Licence conditions.

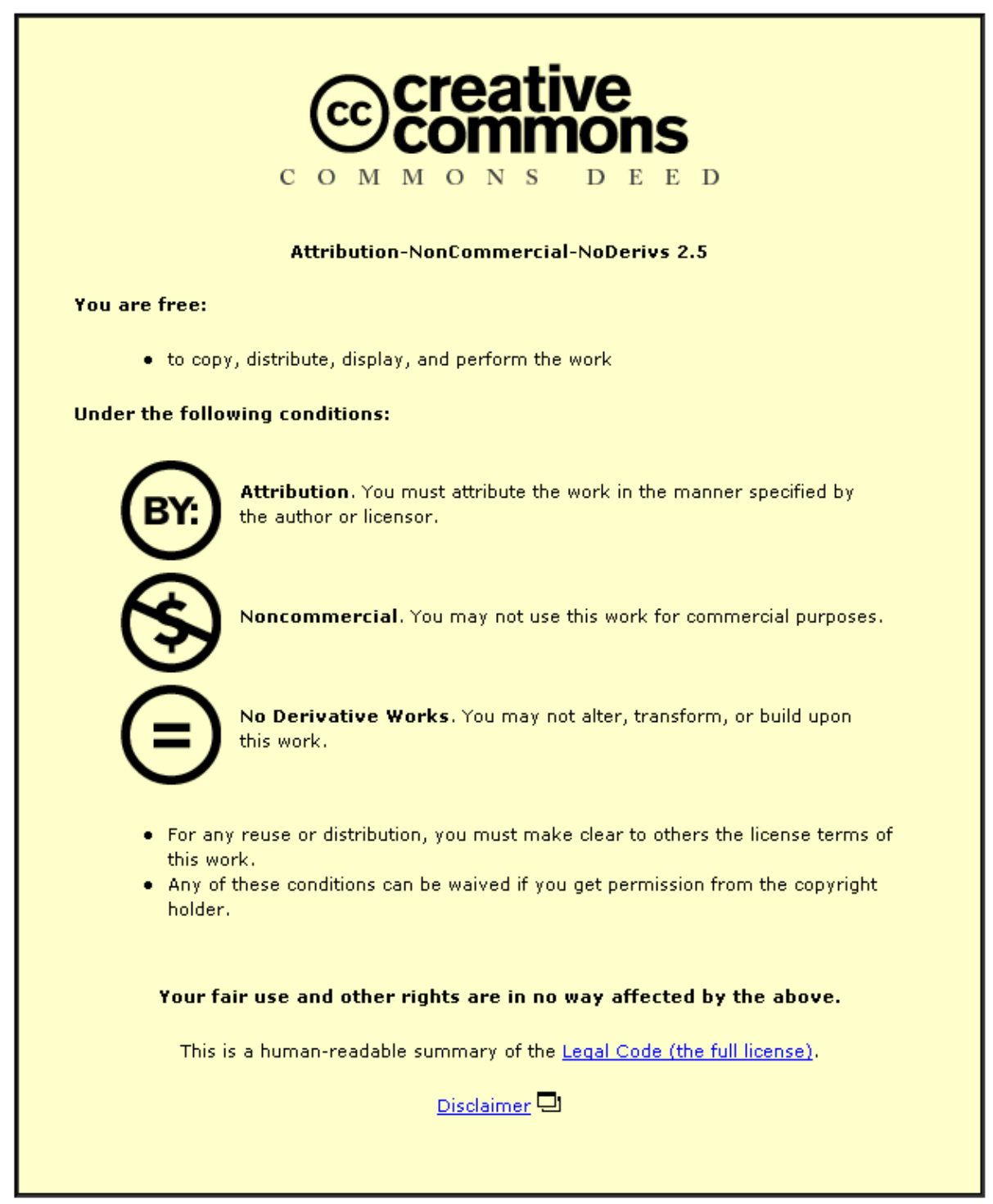

For the full text of this licence, please go to: http://creativecommons.org/licenses/by-nc-nd/2.5/ 
British Politics (2010) 5, 436-454. doi: 10.1057/bp.2010.18

\title{
Patterns of press partisanship in the 2010 General Election
}

\author{
Dominic Wringa and David Deacona \\ ${ }^{a}$ Communication Research Centre, Department of Social Sciences, Loughborough \\ University, Leicestershire LE11 3TU, UK. E-mail: d.n.deacon@lboro.ac.uk \\ Correspondence: Dominic Wring, E-mail: d.j.wring@lboro.ac.uk
}

Introduction

Prior to the 2010 General Election there was widespread acknowledgement that it would be a closer race than the previous few campaigns. This factor intensified the speculation that is often commonplace before elections as to the possible role and effects of the media. This time a good deal of the discussion focused on the likely impact of the first ever televised leaders' debates. Furthermore there was also renewed interest in the potential of online campaigning given the growth of internet phenomenon such as Twitter, Facebook, YouTube and other popular websites (Wring and Ward, 2010). This paper, however, considers the part played by the oldest mass medium, the newspaper. Despite declining sales and the rise of alternative platforms such as the blogosphere, the national press still enjoys a wider readership amongst the voting public. Print journalism, in its various guises, also continues to inspire the devotion or else fear in most of leading politicians vying for office. This may of course change in the future with the further erosion of newspaper circulations but for now these titles continue to inform and influence the electoral agenda.

2010 was the first campaign since 1992 in which the Conservatives were returned to government. Both elections were also the focus of some debate over the role and motives of certain media proprietors, particularly in close contests like these. Famously after 1992 the best-selling daily newspaper ran the headline 'It Was The 
Sun Wot Won It' and sentiments of that kind contributed to a major evaluation and examination of the relationship between the print media and British politics after the campaign (Curtice and Semetko, 1994; Linton, 1995). By the time of the 1997 election the paper had transferred its allegiance to the by now Tony Blair led Labour opposition. In 2010 the title returned to supporting the Conservatives and there was a by now familiar kind of speculation as to the motives behind the change and its possible electoral consequences. It is, however, important to recognize that although the Sun commands a significant audience and it and its owners are often the subject of most speculation, other newspapers have also revised their views of politicians during a couple of decades which has seen unprecedented fluctuations in the levels of support for the main parties. This article considers press partisanship during the 2010 General Election and most especially the strength of the various endorsements and how these compare with recent campaigns. Consideration is also given to the quantitative as well as qualitative nature of this coverage.

\section{The Murdoch Press}

Gordon Brown received a reasonably favourable press during the first few months of his leadership but this positive treatment began to dissipate in the latter stages of 2007, particularly after the new Prime Minister allegedly reneged on a plan to call an election that autumn. Thereafter he never regained the initiative and he appeared at the mercy of events, notably those associated with the economic crisis that deepened throughout 2008. It seemed unlikely that Brown would enjoy anything like the media coverage and endorsements his predecessor Tony Blair had received in each of the three general elections he had fought as party leader. This was confirmed when the Sun declared it would switch back to supporting the Conservatives for the first time in a national election since 1992. The influential daily, which sells around three million per issue, did so just after Gordon Brown's speech to his party conference in autumn 2009 in a move evidently designed to detract from and undermine his appeal to the electorate. This change of allegiance was in part motivated by an expectation of as well as a desire to see a Conservative 
victory and thereafter the newspaper ran a series of damaging stories about Brown's apparent character defects. Some of the revelations focused on the Prime Minister's supposedly disrespectful behaviour during a military commemoration as well as his apparent failure to correctly spell the name of a serviceman killed in action in a letter of condolence to the deceased's grieving mother. The armed forces dimension to the coverage continued when the newspaper revealed revered SAS veteran and author Andy McNab was voting Conservative.

During the campaign proper there were several further references to Brown's alleged personal deficiencies but the newspaper's critique of him and the Labour government's performance was temporarily deflected with the emergence of the Liberal Democrats as possible contenders for office in the event of a coalition government. The front page of the election day newspaper was comparatively upbeat with the headline 'Our Only Hope' underneath a picture of the Conservative leader in the style of the iconic red and blue portrait that had been memorably used by Barack Obama supporters in the 2008 US presidential election. The endorsement was subtitled 'In Cameron We Trust' and argued that the Tories were 'the only choice if you want to rescue Britain from disaster'. Inside the paper warned 'Can Britain take five more years of hard Labour?' before listing what it claimed were the party's failures in government. The Sun even revived the possibility of Labour women politicians banning topless page 3 models, a claim it had last made in 1992 when it had last supported the Tories.

Murdoch's other newspapers also endorsed the Conservatives, notably the best selling title of all, the News of the World. For its part the Sunday Times had been the longer standing party supporter and more discernibly right-wing in its political coverage than its daily sister paper. The Times had been close to Blair during this time in office and supportive of him, particularly over his more controversial foreign policy ventures. As is typical for a quality title, its subsequent shift and declaration of its allegiance to the Conservatives was more nuanced than that of the Sun. It did, however, argue that public borrowing had got out of hand and that 'the bills had been 
shoved into the drawer without opening the envelopes' before starkly warning of the potential development of a Greek style tragedy in a reference to the pandemonium that had engulfed Athens in response to the country's government recent announcement of austerity measures to tackle its budget deficit. Like its near namesake, the Financial Times also abandoned Labour having endorsed the party in the four previous general elections. The FT was, however, less forceful in stating its belief that the Conservatives were best place to tackle the fiscal crisis

The changes of partisanship by the Sun, The Times, FT and News of the World were a significant fillip to the Conservatives and the campaign saw a revival in the overall strength of the Tory press not seen since the party's last national victory in the 1992 General Election. After that election Murdoch's paper boastfulness about its own role in that outcome helped trigger the last significant appraisal of media effects with diverse commentators including the former Tory Treasurer Lord McAlpine and defeated Labour leader Neil Kinnock arguing national newspaper coverage had had some impact on the electoral outcome (Harrop and Scammell, 1992). It was perhaps with this in mind that the Independent promoted its own credentials with the slogan 'Rupert Murdoch won't decide this election. You will'. The same campaign, created by leading marketer Trevor Beattie, also challenged the roles of Tory funder Lord Ashcroft and Labour's Unite union donors but neither of these messages had anything like the same impact (Brownsall, 2010). Prior to the election there had been considerable speculation as to what if anything an incoming Conservative government might do that would benefit Murdoch's media interest in return for his newspapers' support. The Independent advert touched on this controversy but few would have predicted the response its subsequently provoked.

Soon after the Independent published its slogans it sparked an impromptu confrontation in the newspaper's headquarters between editor-in-chief Simon Kelner and Murdoch's son and key lieutenant James who was accompanied by Rebekah Brooks, the former Sun editor who manages their News International firm's UK papers. Kelner had not invited the pair who subsequently barged into his office and 
forcefully remonstrated with him about the advertisements. Although the protagonists' own media were reluctant to dwell on the episode, other journalists saw it as highly newsworthy and Channel 4's political correspondent Cathy Newman broadcast an account of what had happened from inside the headquarters of the Independent. If nothing else the encounter between Kelner and his critics revealed the sensitivity of Murdoch executives to the charge that they were seeking to influence the election outcome. Furthermore, as former Sun editor David Yelland saw it, the confrontation reflected unease within the company at the emergence of the Liberal Democrats as potential partners in government. As Yelland argued the third party had been previously been largely ignored by papers belonging to Murdoch's News International group and he interpreted the confrontation with Kelner as a sign of concern inside the media company that the apparent surge in support for the third party might damage their Conservative allies' position (Yelland, 2010).

\section{Tensions Beneath the Surface: the other national newspapers.}

The Independent advertising campaign that provoked such ire also focused on what it and others believed were the shortcomings of a voting system that favoured the two main parties. It was therefore logical that the paper once again took the opportunity to promote the case for the Liberal Democrat as means of realizing 'fundamental electoral reform' after the tumultuous events of the previous parliament. The paper did, however, concede that a Labour vote was preferable where that party was the main contender with the Conservatives. The other liberal left qualities, the Guardian and its Observer sister, adopted very similar stances to the Independent and primarily justified its decision to support the Liberal Democrats because of their shared belief in the merits of electoral reform. The paper also applauded Clegg who, released from the 'arid, name-calling party politics of the House of Commons', had taken 'the chance to shine'. By contrast Gordon Brown was dismissed as a failed leader.

The defection so many erstwhile supporters left the Daily Mirror, Sunday Mirror and 
their Scottish equivalents the Daily Record and Sunday Mail as the only titles still endorsing the incumbent party. Veteran Mirror journalists like Kevin Maguire and Brian Reader provided plenty of knocking copy and the election day front cover emulated its fierce redtop rival the Sun by featuring another arresting image of David Cameron. But it was a very different, more negative portrayal that was based on a photograph of Cameron that had previously been withdrawn by its copyright holder following its earlier publication after he had been elected party leader. The picture, taken in 1987, showed the then Oxford University undergraduate in the full regalia of the exclusive student Bullingdon Club alongside nine fellow members including Boris Johnson. So keen to re-use the image, BBC2 Newsnight had taken to commissioning a portrait artist to recreate the scene. The Mirror evidently had few qualms in taking the risk of printing the iconic photograph to underline its contention that Cameron was the product of privilege unable to relate to ordinary voters' lives. Whilst much of the paper's coverage had focused on the Conservatives' shortcomings, space was also devoted to promoting the Labour case. The Prime Minister's wife, Sarah Brown, was regularly featured in campaign stories and the former public relations executive also published an online diary for the Mirror's website during the election. This and other likeminded activities reaffirmed the close links between the party and its most loyal media supporter, ties that had been strained during a Blair era in which Downing Street had at times appeared keener to cultivate the Sun.

If the Mirror had been Labour's most consistent supporter over the years, the Daily Telegraph and its Sunday sister are arguably the Conservatives' staunchest advocates within the media and the outlets that were perhaps best positioned to directly benefit- through increased access to the key powerbrokers- from their return to office. The daily paper's endorsement of Cameron applauded his efforts to make the party 'more electable' and his 'vision of the Big Society' although the same editorial was more preoccupied with the perceived shortcomings of Labour and the Liberal Democrats. Although it was predictable that the Telegraph would again support the Conservatives its relatively unqualified backing contrasted with some of 
the less than flattering criticisms of the new leadership by prominent commentators associated with the paper such as Janet Daley and Simon Heffer. These and others gave voice to the Tory right's disdain for some of the new leadership's agenda, particularly the perceived move away from the defence of traditional conservative values. That said Cameron had cultivated a good relationship with proprietors the Barclay brothers as well as Will Lewis, the former editor whose tenure at the helm saw significant changes designed to modernize the paper's image.

Simon Heffer had joined the Telegraph from the Daily Mail, the other newspaper most traditionally associated with the centre-right of British politics. It too had been critical of the new Conservative leadership, fearful that he might be an 'heir to Blair', a reference to the paper's vitriolic disdain for the former Prime Minister. The same level of toxic enmity did not translate into coverage of Gordon Brown who remained on reasonably good personal terms with editor in chief Paul Dacre throughout his premiership. In declaring for the Conservatives, the Mail acknowledged that bankers were primarily responsible for the economic crisis although successive Labour governments were blamed for having presided over an expanded public sector. The paper urged readers to vote decisively against the incumbents, the Liberal Democrats as well as the prospect of a hung parliament. The Mail on Sunday adopted essentially the same position although its prominent contributor Peter Hitchens struck a discordant note by calling on voters not to support Cameron because of his belief that the Tory was a leader in the Blair mould supported by 'modish, rich metropolitan liberals' antipathetic to traditional conservative mores. Prior to the campaign the Mail had featured compromising stories about some of the new leaderships' A List candidates who collectively helped promote a less male, white heterosexual image of the party.

The Daily Express, the midmarket rival to the Mail, adopted a similar position in its enthusiastic endorsement of the Conservatives. It underlined its right-wing populism by, along amongst the national newspapers, applauding the anti-European Union UKIP although it also acknowledged a vote for the party was essentially wasted. 
The Sunday Express also supported the Conservatives, reiterating concerns over immigration, welfare, debt and Labour failures shared by each of the other Tory press titles. Although owned by Express proprietor Richard Desmond, the Star did not emulate his other papers and was the only daily not to endorse a party. It did, however, advocate voting if only because it was, as it put it, 'Time to give 'em a kick in the ballots!' in reference to the politicians' expenses scandal, broken promises and negative campaigning. But coverage in the Star was also somewhat intriguing because there was an obvious disconnect between its declared non-partisanship and an ideological standpoint that was in many ways as right-wing populist as the Express. This was evident in some of the paper's more routine coverage during the campaign and which touched on political issues such as immigration and most especially welfare claimants. In a strong echo of an official Conservative advertisement the Star identified and criticized supposed abuses of the benefits system by focusing on personal cases. In its General Election day editorials the paper suggested readers could make up their own minds whilst simultaneously attacking a 'sponger' who was too lazy to vote and, by extension, the incumbent government that had enabled him to make his supposedly dubious claims.

\section{From Tory to Tony and Back Again: Changing Patterns of Press Partisanship.}

The previous discussions of press partisanship are informed by close analysis of the various newspapers' editorial endorsements. Obviously these statements are only one dimension of the given title's political output but they are often the single most important indicator of their affiliation. Editorials of this are typically self-conscious and can be lengthy, detailed statements. Moreover they are the result of discussions involving the most senior executives, the composition of which varies between newspapers but involves a selection of editors, leader-writers and possibly the proprietors (Firmstone, 2008). Table 1 provides an overview of national newspaper editorial endorsements in 2010 as well as the previous four elections dating back to 1992, the last campaign in which the Conservatives were returned to office. The analysis is based on close scrutiny of all the papers' declarations of support, usually 
though not exclusively published on polling day. Furthermore an important dimension of this study relates to the strength of the endorsement because it is arguably not simply enough to identify if a title supports a party. Consequently it is important to understand the intensity of the affiliation and how this changes over time. The attribution of Strong/Very Strong is given to a paper that makes an unconditional endorsement whereas Moderate describes an editorial with some qualification of the allegiance and Weak/Very Weak relates to the mildest of testimonials (Deacon and Wring, 2002).

\section{TABLE 1 ABOUT HERE}

Tables 2 and 3 adapt the data from 1 and chart the fluctuating levels of partisanship in the five elections held between 1992 and 2010. Both identify a similar trend and one that is to be expected because, as has been discussed, most of the Sunday papers tend to replicate their daily sisters' patterns of endorsement. The Tables confirm an elementary point: the party that won the most votes at each election also received the majority of support in terms of press backing if calculated according to the level of circulation.

Table 2

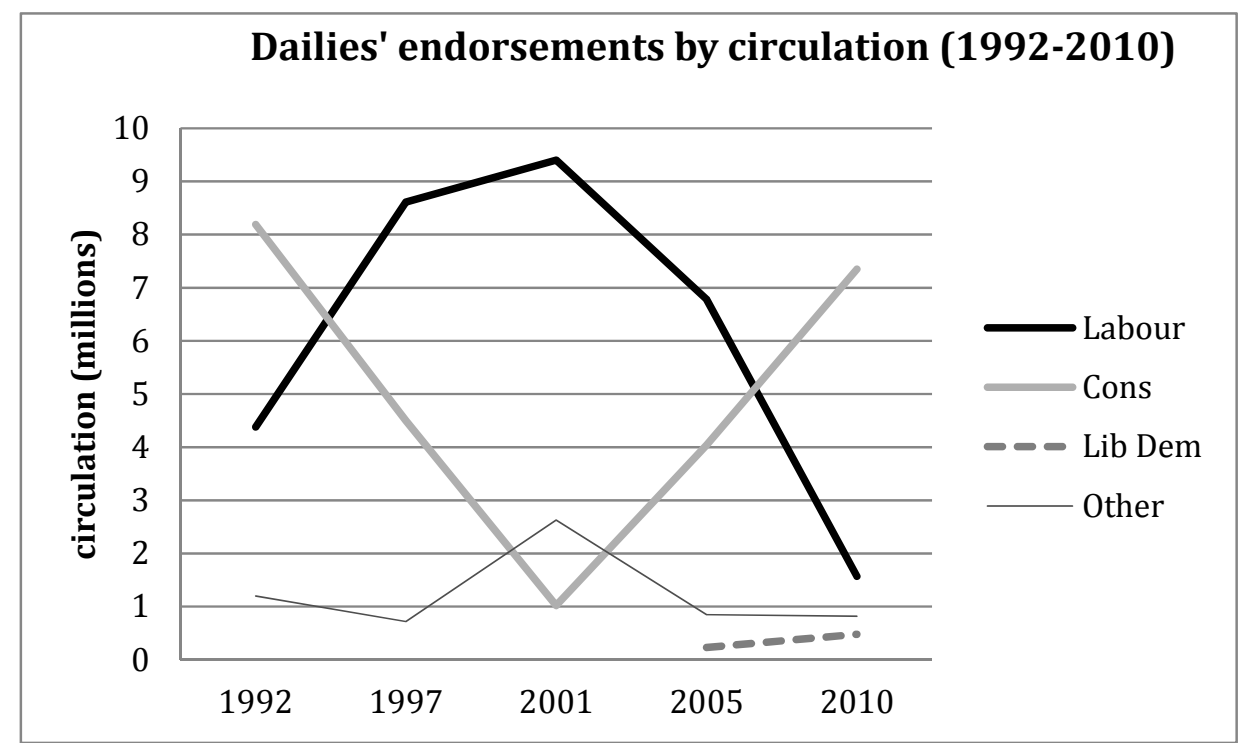

Table 3 


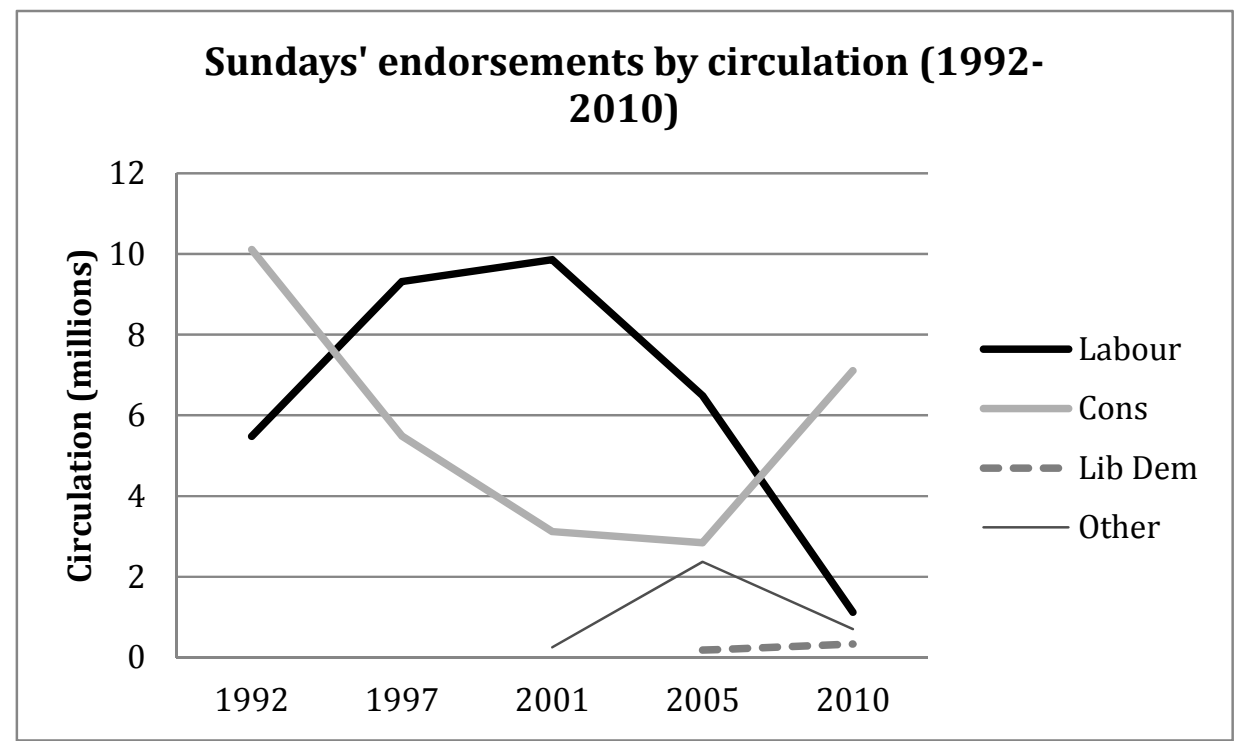

It should be noted that the leads in circulation terms between 1997-2005 were unique for Labour and that 1992 and 2010 are more representative of the historic pattern that has worked to the advantage of the Conservatives since the granting of near universal suffrage in 1918. That said this revival of the Tory press is somewhat diminished by the overall decline in newspaper readership over the last two decades (see Table 4). Consequently although the Conservatives' enjoyed a larger lead in print media terms over Labour in 2010 than they did in 1992, the downward trend in circulation between these two campaigns inevitably diminishes the electoral potency of the press. Tory levels of support were therefore $9 \%$ less for dailies and $30 \%$ lower for Sundays comparing the start and end of the period covered by Table 4 .

Table 4 


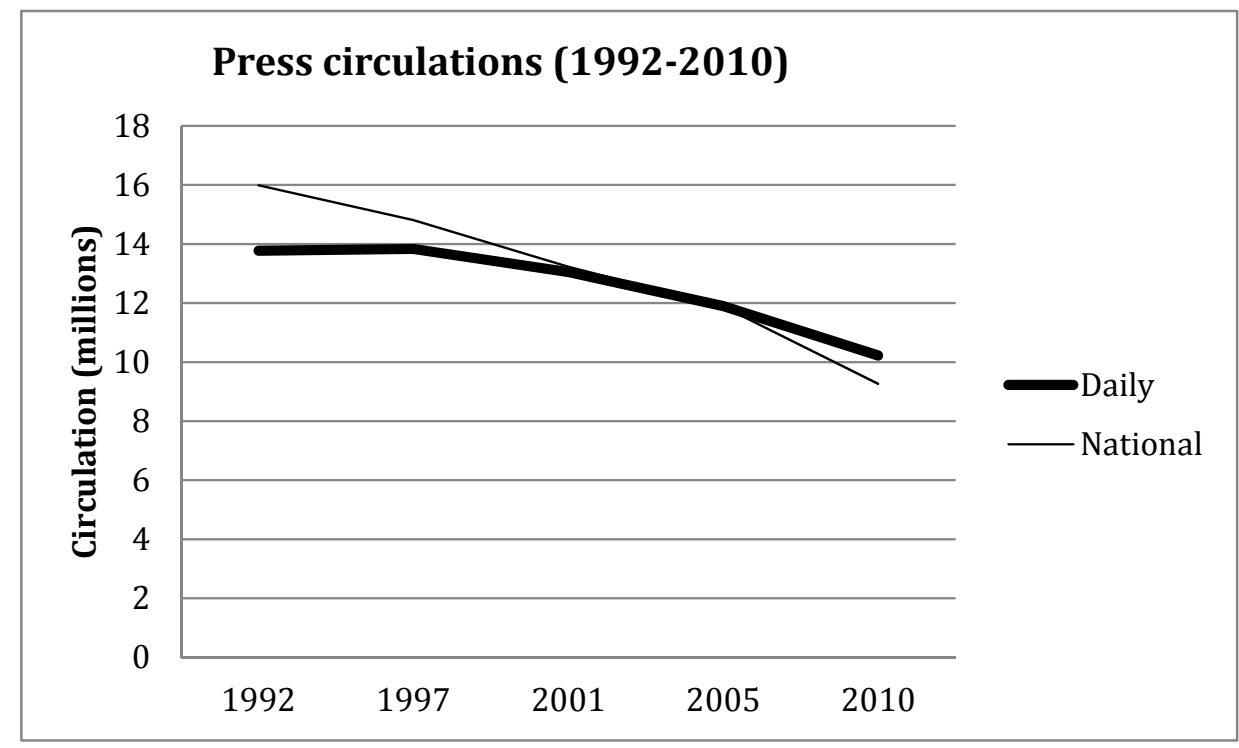

Whereas Tables 2-4 review the headline trends in terms of newspaper circulations the following consider the fluctuating strengths of partisan endorsement. When considered in purely numerical terms, Labour's leads in endorsements throughout the period 1997-2005 are comparable to those for the Conservatives in 1992 and again in 2010. However as Tables 5 and 6 demonstrate the strengths of this support differs in a qualitative sense. Consequently although Labour enjoyed leads in the three elections it won, these endorsements were characteristically weaker, more conditional and devoted to the leader rather than his party. Such editorializing was representative of the so-called 'Tony press' effect during this era. By contrast the Conservative triumphs in 1992 and 2010 received the more enthusiastic backing of their press supporters. Yet the revival of the Tory press in the latter campaign did not result in the kind of widespread debate over the titles' supposed influence that took place after the 1992 campaign. This is arguably because the circulation of these titles has declined in the interim and with it their perceived ability to influence the wider news and public agenda.

Table 5 


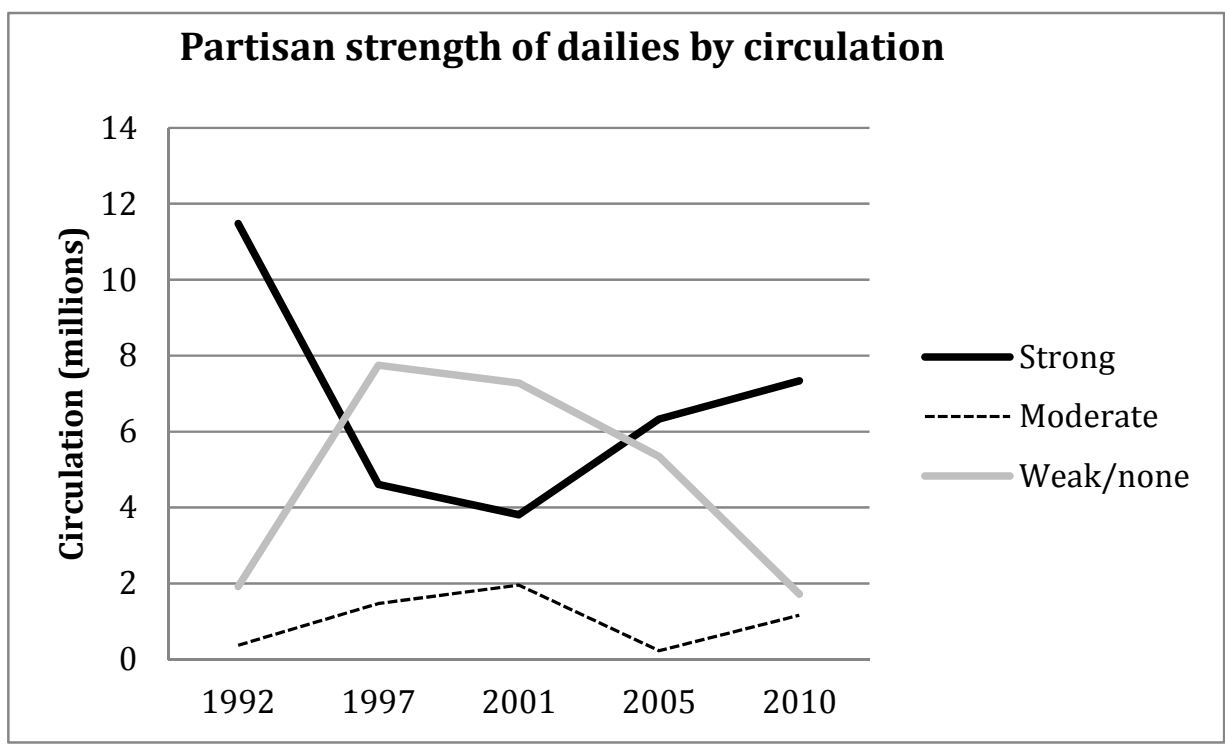

Table 6

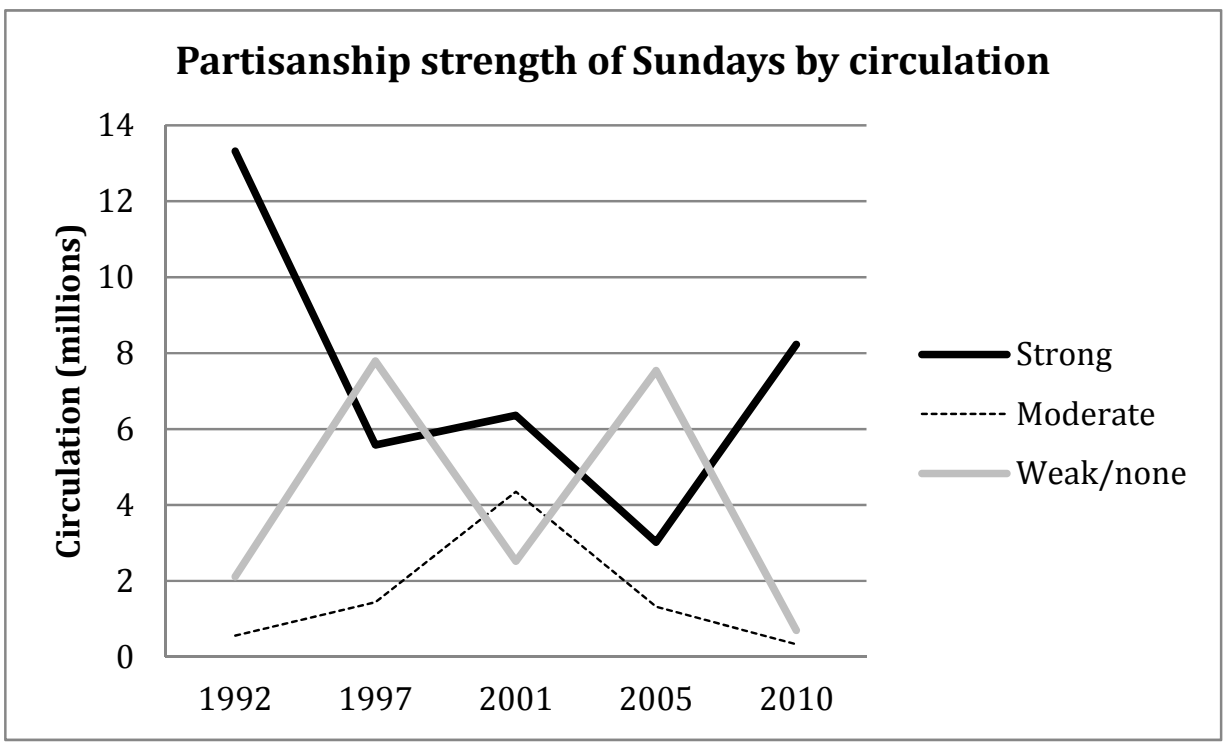

The Press Agenda

Editorials are, as has been noted, only one dimension to a given newspaper's coverage and it is of course doubtful whether many readers are unduly interested or let alone swayed by a particular endorsement. Arguably more important is the routine coverage and the way various events and personalities are duly represented to the voting public. During the election any number of topics vied with the politicians 
for space on the news agenda. A prime example of this was the eruption of the Icelandic volcano that disrupted air travel for days, dominating the headlines for a not insignificant period during the campaign. Similarly gossip invariably featuring celebrities often dominated the more popular and populist newspapers throughout this period. This focus on human interest stories has helped to shape the nature of some election coverage and this trend has been further exacerbated by politicians who have been keen to promote themselves as people in touch with the concerns of the lay voter. The leaders' preoccupation with being seen to relate to ordinary everyday concerns informed much of their approach as well as some of the defining moments of the campaign, most notably the notorious encounter between Gordon Brown and erstwhile Labour supporter Gillian Duffy on his visit to Rochdale. Predictably the reactions of the various newspapers to incident accorded with their partisan outlooks. Where the Mirror attempted to offer excuses the Mail on Sunday ran a damaging interview with Mrs Duffy that revealed she would not be voting after the Prime Minister had called her 'bigoted' in a private conversation that was recorded and later broadcast.

The so-called 'Duffygate' was one of the most prominent albeit atypical incidents during the campaign. Table 7 considers the campaign as a whole by reviewing how and what the major media reported. ${ }^{1}$ The five most prominent themes are identified as are calculations for each of these based on the percentage of items sector by sector. The generic theme of 'electoral process' was the lead story across all media and most especially the popular newspapers. Some of this related to so-called 'horserace' topics such as party strategising and the state of the opinion polls. The process category has been the most prominent single feature in the reporting of previous campaigns although it was greater in 2010 not

\footnotetext{
${ }^{1}$ The study covers the period from the first full day of the campaign, i.e. after the one after it was called, right through to polling day. The broadcasting sampled covered the main news programming, i.e. BBC 1 10pm News, BBC2 Newsnight, ITV News at 10pm, Channel 4 News 7pm, Channel 5 News 5pm, Sky News 9pm bulletin, BBC Radio 4 Today 0730-0830 and BBC Radio 1 Newsbeat 1745-1800. The entire national newspaper market was also analysed. 'Quality' titles refers to the following: the Guardian, Observer, Telegraph, Sunday Telegraph, Times, Sunday Times, Financial Times, Independent, Independent on Sunday; 'midmarket' means the Mail, Mail on Sunday, Express, Sunday Express; and 'populars' is a synonym for the so-called 'red tops' which are the Sun, News of the World, Mirror, Sunday Mirror, People, Star and Star on Sunday.
} 
least because of the extensive attention devoted to the leadership debates and the prospect of a hung parliament.

Table 7: Top Five Elections Themes

$\begin{array}{lllll} & \text { Broadcast } & \text { Quality } & \text { Midmarket } & \text { Popular } \\ \text { Electoral Process } & 68 & 68 & 64 & 80 \\ \text { Economy } & 31 & 44 & 44 & 32 \\ \text { Taxation } & 11 & 15 & 7 & 8 \\ \text { Standards } & 5 & 9 & 25 & 15 \\ \text { Immigration/Race/Religion } & 8 & 6 & 16 & 7 \\ \text { Number of items } & 1304 & 784 & 294 & 458\end{array}$

Table 7 demonstrates that there were statistically significant variations across the sampled media. Aside from process there was a number of what might be termed more substantive topics that were covered with differing degrees of intensity. The 'Economy' was markedly more prominent in the so-called quality and midmarket press whereas 'Taxation' received greater attention in the broadcast and quality print media. Arguably more striking was the variation in the amount of coverage devoted to standards in public life. Here there was noticeably less attention from the quality newspapers that had collectively done so much to promote the original story of the scandal over MPs' expenses claims during the last parliament. Rather it was the midmarket and popular newspapers that attempted to rekindle interest in the issue during the campaign. Similarly there was a sizeable difference in the coverage of immigration and topics routinely associated with it such as race, asylum and religion. The midmarket titles' noticeable preoccupation with this story is evidence of a 'Desmond-Dacre effect' whereby those respectively responsible for editorial policy at the Express and Mail made a concerted attempt to ensure an issue of particular concern to them was given greater electoral prominence. 


\section{The Leadership Debates}

The 2010 campaign was partly dominated by the reporting of the leadership debates, the first of their kind ever held in a UK General Election. Nearly 10 million people watched the historic opening encounter on ITV, a record for a current affairs programme and an audience second only to Britain's Got Talent that week. Collectively the encounters were referred to in nearly a quarter of the coded items although some of these mentions were incidental rather than prominent. Perhaps predictably it was the broadcast media that aired the programmes that also devoted most attention to them (Table 8). By contrast the quality press, with its tendency to want to focus on substance rather than personality, offered the least coverage.

Table 8 Media coverage referring to leadership debates

$\begin{array}{ll}\text { All } & 24 \% \\ \text { Broadcast } & 28 \% \\ \text { Quality } & 19 \% \\ \text { Midmarket } & 22 \% \\ \text { Popular } & 23 \%\end{array}$

Another perhaps predictable trend was the declining media interest in each of the successive debates (Table 9). Nearly half of all coverage of them focused on the first encounter and there was more comment about the second than the last. That said there was of course more time for discussion prior to the opening debate.

Table 9 Share of leadership debate coverage devoted to each encounter

$$
\text { Broadcast Quality Midmarket Popular }
$$

$\begin{array}{lllll}\text { First } & 48 & 52 & 47 & 49 \\ \text { Second } & 27 & 25 & 22 & 27 \\ \text { Third } & 24 & 16 & 16 & 17\end{array}$


$\begin{array}{lllll}\text { Various } & 0 & 8 & 16 & 7\end{array}$

$\begin{array}{lllll}\text { Number } & 364 & 151 & 64 & 107\end{array}$

There was considerable interest in public evaluations of the leaders' performance in the debate as reflected in opinion research and other feedback mechanisms. Table 10 reviews how the various sectors rated each candidate. The less prominent figure Nick Clegg took advantage of the substantial publicity opportunity afforded him by the contests. Polls, particularly those taken after the first debate, appeared to vindicate Clegg's approach and suggested he had come out best from the encounter. Similarly the reactions of the various media were positive with nearly half of his appearances judged favourably. The quality press and broadcasters were especially fulsome about the Liberal Democrat. Conversely Gordon Brown fared less well, particularly in the midmarket press evaluations of the leadership debate outcomes. Overall David Cameron performed credibly although neither he nor Brown received the level of clear evaluative assessments that Clegg did. Clearly the leader least likely to become Prime Minister scored well in public not to mention media reactions to the debates.

Table 10 Media evaluations of the main party leaders

\begin{tabular}{|c|c|c|c|c|c|c|}
\hline & & All & Broadcast & Quality & Midmarket & Popular \\
\hline & & $\%$ & $\%$ & $\%$ & $\%$ & $\%$ \\
\hline Brown & Positive & 8 & 9 & 6 & 3 & 13 \\
\hline & Negative & 20 & 14 & 14 & 33 & 26 \\
\hline & Mixed/unclear/no & & & & & \\
\hline & evaluation & 72 & 77 & 80 & 64 & 61 \\
\hline & Number of cases & 389 & 118 & 102 & 63 & 106 \\
\hline Cameron & Positive & 21 & 15 & 20 & 29 & 23 \\
\hline & Negative & 10 & 4 & 12 & 6 & 15 \\
\hline & Mixed/unclear/no & & & & & \\
\hline & evaluation & 70 & 81 & 68 & 65 & 62 \\
\hline
\end{tabular}




\begin{tabular}{lllllll}
\hline & Number of cases & 391 & 120 & 103 & 63 & 105 \\
\hline Clegg & Positive & 38 & 41 & 53 & 34 & 21 \\
& Negative & 8 & 2 & 5 & 11 & 15
\end{tabular}

Mixed/unclear/no

\begin{tabular}{llllll} 
evaluation & 54 & 57 & 42 & 55 & 64 \\
\hline Number of cases & 406 & 126 & 112 & 62 & 106 \\
\hline
\end{tabular}

The first of the leadership debates was arguably the turning point of the General Election because it proved to be a considerable boost for Clegg and helped him emerge as the clear public voice of the Liberal Democrats, a role in part previously occupied by his articulate deputy Vince Cable. The outbreak of what was termed 'Cleggmania' followed on from the opening debate and from positive poll reactions to the leader. Furthermore the Liberal Democrat's strong performance destabilized the Conservatives' strategy through presenting himself as a credible alternative to Cameron as the candidate for change. The surge in media sympathy and interest in Clegg also triggered a more negative response on the eve of the second debate. This formidable counterattack was launched through the pages of the Tory press and its merciless focus on the alleged deficiencies of Clegg and his party was reminiscent of some of these papers' anti-Labour campaigns in the 1980s. But this effort was somewhat different because its third party target had previously been largely neglected. Furthermore the motive behind the criticism appeared to be more opportunistic and driven by electoral considerations.

Prior to the second leadership debate Nick Clegg and the Liberal Democrats were subjected to a barrage of damaging coverage that appeared part of a concerted attempt to limit the party's appeal. The Sun published notes handwritten by Clegg's chief strategist implying it was somehow underhand for him to prepare for the debates. The Express was vituperative about aspects of the Liberal Democrats' policies, particularly those on immigration. Perhaps the most striking campaign headline appeared on the front page of the Mail. 'Clegg's Nazi slur on Britain' 
claimed a piece published in the Guardian by the then MEP in 2002 amounted to a stinging criticism of the nation's inability to come to terms and move on from the Second World War. The Mail interpretation of the hitherto forgotten article provided lurid copy as did the same paper's 'the United Nations of Nick Clegg', a feature questioning of his Britishness on account of Dutch mother and other foreign relatives and acquaintances. Perhaps the most potentially damaging story appeared in the Daily Telegraph and had the potential to revive memories of an expenses' scandal that had originally been published in that newspaper. The paper disclosed that Clegg had received payments from supporters that had been paid into his own personal bank account. The leader dismissed the assertion that the transactions were evidence of impropriety. Peter Mandelson, the head of Labour's election strategy, attacked what he alleged was a concerted attempt by the Conservatives to smear their mutual rivals. Similarly the Liberal Democrat campaign manager Danny Alexander demanded his Tory counterpart George Osborne 'come clean' on his party's involvement in the press offensive.

\section{The Readers' Vote.}

It is notoriously to isolate and identify media effects, particularly in an election that is a complex, multifaceted event in which audiences are subjected to a range of information sources and socialization processes. The British press has, however, been the focus of past debates, notably after 1992, as to the persuasive impact of stimuli during campaigns. Table 11 considers how the readers of different newspapers voted in 2010 and compares the figures with patterns of support in 2005. Most changes were in line with the approximately $5 \%$ national swing to the Conservatives with a couple of exceptions, the Sun and the Star. The 13.5\% swing amongst Sun readers is by far the most significant figure and not only because it is the largest. This switch of allegiance raises the issue of whether the paper's shift to the Tories was a significant factor in encouraging its audience to similarly defect or rather merely following their lead. Furthermore the shifts in affiliations maybe linked to a range of demographic changes related to the evolving profile of the readership. 
These factors include class, gender, age and ethnicity but even these together may not explain the level of swing within the Sun readership. And of course this was the first campaign since 1992 when the party's endorsement was both Conservative and without the caveats attached to its support for Labour.

Table 11 Voting behaviour of newspaper readerships

\begin{tabular}{|l|l|l|l|l|}
\hline $2010(\& 2005)$ & & & \\
\hline $\begin{array}{l}\text { Daily Press } \\
\text { Result }\end{array}$ & $\begin{array}{l}\text { Lab } \\
29(35)\end{array}$ & $\begin{array}{l}\text { Cons } \\
36(32)\end{array}$ & $\begin{array}{l}\text { LD } \\
23(22)\end{array}$ & $\begin{array}{l}\text { Swing } \\
5 \text { Lab-Con }\end{array}$ \\
\hline The Independent & $32(34)$ & $14(13)$ & $44(44)$ & 1.5 \\
\hline The Times & $22(27)$ & $49(38)$ & $24(26)$ & 8 \\
\hline The Telegraph & $7(13)$ & $70(65)$ & $18(17)$ & 5.5 \\
\hline The Star & $35(54)$ & $21(22)$ & $20(15)$ & 10 \\
\hline The Daily Express & $19(28)$ & $53(48)$ & $18(18)$ & 7 \\
\hline The Daily Mail & $16(22)$ & $59(57)$ & $16(14)$ & 4 \\
\hline The Sun & $28(45)$ & $43(33)$ & $18(12)$ & 13.5 \\
\hline The Mirror & $59(67)$ & $16(11)$ & $17(17)$ & 6.5 \\
\hline The Guardian & $46(43)$ & $9(7)$ & $37(41)$ & $3.5($ LD-Lab) \\
\hline
\end{tabular}

The Sun has demonstrated that it is more politically promiscuous than other newspapers and keen to be seen to support the winning party at election time. Most of its rivals are less opportunistic. They also reflect (or possibly shape) their own readerships' political persuasions. Table 11 shows that most newspapers support the party that is also the first choice for the largest section of their audience. The only exceptions to this in 2010 were the Guardian and Star. The former's switch to the Liberal Democrats was a belated move announced shortly before polling day, perhaps paradoxically the paper's readers actually swung in the opposite direction and back to Labour albeit by a smallish margin of $3.5 \%$. More striking perhaps were the figures for the Star, the only daily that did not declare an allegiance for a party although, as has been noted, it exhibited certain ideological preferences on some salient campaigning issues. The sharp 
fall in support for Labour within its readership did not, however, lead to an enthusiastic swing to the Conservatives. This perhaps underscores one of the features of this trend, specifically that it is a sign of voter dealignment rather than realignment.

\section{Conclusion}

The 2010 General Election has been characterized as a potentially transition one in media and communication terms partly because online campaigning has yet to realize its full potential such that it ever will achieve the ubiquity that some of its advocates claim (Wring and Ward, 2010). Furthermore the introduction of the leadership debates once again focused attention on broadcast television as a political medium. It was not insignificant that Sky News had been pivotal in first challenging and then encouraging the main leaders to face one another during the campaign. That the channel was able to facilitate one of the subsequent debates underlined its growing influence and status. However political editor Adam Boulton's handling of that encounter, or more specifically his apparent transgression in asking Nick Clegg about his financial affairs in light of Telegraph disclosures, provoked accusations of bias that are perhaps more readily leveled against Sky because the company is part of the Murdoch family controlled News Corporation that also includes the highly ideological broadcasters such as the highly conservative US based Fox News. As has been noted the same group publish several influential opinion forming newspapers in the UK and there has been speculation, particularly with these titles' marked changes of allegiance in recent years, that their owners have granted endorsements in order to gain access and leverage with successive governments to lobby for changes that favour their business interests. Considerations of media power therefore need to appreciate the context in which the platform operates as well as its actual content. However not every major British newspaper publisher retains interest in other parts of the sector and, as this article has discussed, it is still important to understand and analysis the dynamics of press partisanship as evidence through 
their election reporting.

Newspaper circulations have markedly decline in recent years and noticeably over the course of the last five General Elections including 2010. Yet the daily sales figures collectively match the size of the audience that watched the first ever leaders' debate during the campaign and this is a primary reason why the oldest mass medium still retains the ability to influence politicians' thinking if not necessarily their readers' voting although the latter topic remains contentious (Curtice, 1997; Newton and Brynin, 2001). Here it is important to consider not just the direction of partisan support, specifically which newspaper endorses a particular party, but also the strength of commitment. A major issue then is the degree to which an editorial advocates a viewpoint. A lukewarm endorsement is by definition qualitatively different from a more strident one so that a title's support for a party can be little more than perfunctory. By contrast a stronger affiliation often manifests in the strident tone of the coverage, some or most of which might be devoted to vituperative attacks on electoral opponents. 2010 saw a revival in this kind of attack journalism and more especially in the Tory press response to so-called 'Cleggmania'. But this response to the surge of interest in the Liberal Democrats following the first debate may have been too sudden, too obviously self-serving as well as too late to make a discernible impact. Arguably the real influence of the press such as it ever existed lay in its ability to cultivate readers over the medium to long term. The decline in circulation does of course challenge this but newspapers are set to remain a part of the electoral landscape for the foreseeable future.

\section{References}

Brownsall, A. (2010) 'The Independent launches election-themed campaign', Media Week, $21^{\text {st }}$ April.

Curtice, J. (1997) 'Is the Sun Shining on Tony Blair? The Electoral Influence of British Newspapers', Harvard International Journal of Press/Politics, 2: 2, pp. 9- 
26.

Curtice, J. and Semetko, H. (1994), 'Does It Matter What the Papers Say?', in Heath, A. et al (eds.), Labour's Last Chance? The 1992 General Election and Beyond. Aldershot: Dartmouth, pp. 43-64.

Deacon, D. and Wring, D. (2002) 'Partisan Dealignment and the British Press', in Bartle, J. et al (eds.) Political Communications: the British General Election Campaign of 2001, London: Frank Cass, pp.135-49.

Firmstone, J. (2008) 'The editorial production process and editorial values as influences on the opinions of the British press towards Europe', Journalism Practice 2: 2, pp.212-29

Harrop, M. and Scammell, M. (1992) 'A Tabloid War', in Butler, D. and Kavanagh, D., The British General Election of 1992, Hampshire: Macmillan, pp.180-210.

Linton, M. (1995) 'Was it the Sun Wot Won It?', Guardian Lecture, Nuffield College Oxford, October.

Newton, K. and Brynin, M. (2001), The National Press and Party Voting in the UK. Political Studies, 49, pp.265-85.

Wring, D. and Ward, S. (2010) The Media and the 2010 Campaign: the Television Election, Parliamentary Affairs, 63:4

Yelland, D. (2010) 'Nick Clegg's rise could lock Murdoch and the media elite out of UK politics', Guardian, $19^{\text {th }}$ April

Keywords: Media, Newspapers, Partisanship, Election, Voters

Abstract: From a communications perspective much of the commentary and analysis of the 2010 General Election focused on the possible influence of the first ever televised leaders' debates as well as the burgeoning range of online social networking sites. This article, however, concentrates on the role of that most traditional medium, the national press. The British newspaper industry has been a notable political actor; it has been as controversial as it has been overtly partisan. Arguably there have, however, been some changes to this in recent years arising from Labour's electoral successes and the resulting 'Tony press' 
which was markedly less strident in its coverage and more supportive of the leader rather than his party. 2010 was interesting because there a revival of the so-called 'Tory press' in that these titles adopted a stridency not witnessed since the Conservatives last won an election in 1992. Consequently there is a discussion of why certain newspapers switched allegiances and how this impacted on their reporting. Attention is also given to the differences in campaign reporting by the three sectors of the press, and how the various newspaper readerships voted. 